\title{
VARIABILITY OF THE ARBUTIN CONTENT IN WILD GROWING POPULATIONS OF ARCTOSTAPHYLOS UVA-URSI (L.) SPRENG FROM KORAB MOUNTAIN, WESTERN BALKAN
}

\author{
G. Stefkov ${ }^{1}$, I. Cvetkovikj Karanfilova ${ }^{2}$, V. Labroska ${ }^{3,4}$, O. Krsteska ${ }^{1}$, B. Qazimi ${ }^{5}$, \\ M. Karapandzova ${ }^{1}$, Zyber Gjoni ${ }^{6}$, Nikoll Bardhi ${ }^{7}$, S. Kulevanova ${ }^{1}$ \\ ${ }^{1}$ Institute of Pharmacognosy, Faculty of Pharmacy, Ss. Cyril and Methodius University, \\ Skopje, R. N. Macedonia \\ ${ }^{2}$ Center for Natural Products, Faculty of Pharmacy, Ss. Cyril and Methodius University, \\ Skopje, R. N. Macedonia \\ ${ }^{3}$ The National Center for Drug Screening and CAS Key Laboratory of Receptor Research, \\ Shanghai Institute of Meteria Medica, Chinese Academy of Sciences (CAS), Shanghai 201203 \\ ${ }^{4}$ University of Chinese Academy of Sciences, Beijing 100049, China \\ ${ }^{5}$ UBT- Higher Education Institution, Faculty of Pharmacy, Prishtina, R. Kosovo \\ ${ }^{6}$ University of Durres, Albania \\ ${ }^{7}$ Department of Crop Production, Faculty of Agriculture and Environmental, \\ Agricultural University, Tirana, Albania \\ gstefkov@yahoo.com
}

Due to the presence of arbutin and hydroquinone in the bearberry plant (Arctostaphylos uva-ursi (L.) Spreng., Ericaceae), it is widely used as a urinary tract antiseptic and diuretic. The herbal substance consists of whole or cut dried leaves, and it should not contain less than $7.00 \%$ of anhydrous arbutin (Ph.Eur.10). The supply of this herbal substance in Balkan countries mainly comes from a wild plant harvested in the mountains. It is a common practice to collect the leaves during the flowering season of the plant (June-July). There is an abundance of wild growing natural populations of bearberry on Korab Mountain that represents a unique natural resource of this herbal substance for both countries, Albania and N. Macedonia. The aim of the present study was to determine the arbutin content and to assess its variability in the bearberry leaves of seven wild populations from Korab Mountain. The leaves were collected monthly (May-October) during a period of 3 years (2014-2016). The HPLC assay (Ph.Eur.10) revealed that all populations have arbutin content over $7.00 \%(7.03-9.42 \%)$ and that the highest content of arbutin can be attained in September/October, during the phase after the fructification. Statistical analysis showed that there is significant difference between the content of arbutin in the different populations. The content was related to the altitude of the collection site and the collection month and year.

Keywords: arbutin; HPLC; bearberry; technical maturity; R. N. Macedonia; R. Albania

\section{ВАРИЈАБИЛНОСТ НА СОДРЖИНАТА НА АРБУТИН КАЈ ДИВОРАСТЕЧКИТЕ ПОПУЛАЦИИ НА ARCTOSTAPHYLOS UVA-URSI (L.) SPRENG ОД ПЛАНИНАТА КОРАБ, ЗАПАДЕН БАЛКАН}

Поради присуството на арбутин и хидрохинон, мечкиното грозје (Arctostaphylos uva-ursi (L.) Spreng., Ericaceae) широко се користи како уринарен антисептик и диуретик. Хербалната суровина се состои од цели или исечени сушени листови, кои не смеат да содржат помалку од 7,00 \% безводен арбутин (Ph.Eur.10). Во балканските земји главен извор за снабдување со оваа хербална суровина се диворастечките растенија собрани на планините. Вообичаена практика е листовите да се собираат во сезоната на цветање на растението (јуни-јули). На пограничната 
планина Кораб има изобилство природни популации, кои претставуваат природен ресурс за снабдување со оваа хербална суровина за две држави, Албанија и С. Македонија. Целта на оваа студија беше да се утврди содржината на арбутин и да се процени неговата варијабилност во листовите на мечкиното грозје од седум диворастечки популации на планината Кораб. Листовите беа собирани месечно (мај-октомври), во период од 3 години (2014-2016). HPLC-анализата (Ph.Eur.10) покажа дека сите популации содржат над 7,00 \% (7,03-9,42\%) арбутин и дека највисоката содржина на арбутин е забележана во септември/октомври, во периодот по созревање на плодот. Статистичката анализа покажа дека постои значителна разлика помеѓу содржината на арбутинот кај различните популации. Содржината е зависна од надморската височина на локацијата на собирање, месецот на собирање, како и од годината.

Клучни зборови: арбутин; HPLC; мечкино грозје; техничка зрелост; Р. С. Македонија; Р. Албанија

\section{INTRODUCTION}

Arctostaphylos uva-ursi (L.) Spreng. (family Ericaceae), also known as bearberry or bear's ear, is a small procumbent woody groundcover shrub that is widely distributed on a global level $[1,2]$. The name Arctostaphylos originates from two Greek words, arktos = bear, and staphyle $=$ a bunch of grapes, while uva-ursi in Latin means "bear's grape" (uva = grape and ursus = bear) [3]. Bearberry's small, shiny, evergreen leaves, whole or cut, are used as a herbal substance. The first use of bearberry leaves was literally documented in the Middle Ages in the Welsh "Physicians of Nyddfai" from the $13^{\text {th }}$ century. From the beginning of $19^{\text {th }}$ century, bearberry has been in official use for the treatment of inflammatory disorders of the efferent urinary tract as well as for different diseases such as hydrops, lithiasis, diabetes, gonorrhea, etc. [1, 4].

The herb contains hydroquinone glycosides: arbutin (arbutoside, hydroquinone- $O-\beta$-D-glucoside, 5.00-16.00\%), methyl arbutin ( $O$-methyl hydroquinone- $O-\beta-\mathrm{D}$-glycoside, up to $4.00 \%$ ), galloyl derivatives of arbutin $(0.05 \%): O$-galloyl hydroquinone- $O$ - $\beta$-D-glucoside ( $p$-galloyl oxyphenyl-O$\beta$-D-glucoside), 2'-O-galloyl arbutin, 6'- $O$-galloyl arbutin and free hydroquinone $(<0.30 \%)$ as a decomposition product of arbutin [1, 5]. A lot of phenol carboxylic acids are present: gallic acid (free, $180.00 \mathrm{mg} / 100 \mathrm{~g}$ ), p-coumaric acid (18.00 $\mathrm{mg} / 100 \mathrm{~g})$, syringic acid $(16.80 \mathrm{mg} / 100 \mathrm{~g})$, salicylic acid $(12.00 \mathrm{mg} / 100 \mathrm{~g}), p$-hydroxybenzoic acid $(9.60 \mathrm{mg} / 100 \mathrm{~g})$, ferulic acid $(6.00 \mathrm{mg} / 100 \mathrm{~g})$, caffeic acid $(6.00 \mathrm{mg} / 100 \mathrm{~g})$, lithospermic acid (dimeric caffeic acid), etc. [6]. The content of tannins (acting as an astringent) is quite high (10.00-20.00\%), comprising gallotannins including penta- $O$-galloyl$\beta$-D-glucose and hexa- $O$-gailoyl- $\beta$-D-glucose; ellagi-tannins, including corilagin (1-O-galloyl-3,6-di$O$-hexahydroxydophenol- $\beta$-D-gulcoside); and condensed tannins, chiefly proanthocyanidins and their monomerics, including cyanidin, delphinidin and iridoide: monotropein $(0.025 \%)$. The drug has flavonol glycosides, including hyperoside $(0.80-1.50$ $\%)$, quercitrin, isoquercitrin, myricitrin, myricetin$3-O-\beta$-D-galactoside, and 2 isomeric quercetin arabinosides. There is also the presence of enzymes (arbutase) and triterpenes (ursolic acid). Although all phenol glycosides and their aglycones have an antibacterial effect, the major antimicrobial effect is associated with the aglycon hydroquinone released from arbutin (transport form) or arbutin waste products in the alkaline urine. The drug has urine-sterilizing properties that are attributed to bacteriostatic hydroquinones, primarily conjugates of glucuronic and sulfuric acid. There are no clinical studies available that have been definitively evaluated [1, 6-7]. Nowadays, only its use as a urinary tract antiseptic and diuretic remains, which is due to the presence of arbutin and hydroquinone [8]. The mechanism of action is not clear at present because arbutin alone is reported to show little antimicrobial effectiveness [9]. However, its use for infections of the urinary tract is approved by German Commission E.

According to Ph.Eur.10.0, dried leaf, whole or cut, of A. uva-ursi (L.) Spreng should contain not less than $7.00 \%$ of anhydrous arbutin [10]. The same amount is also stated in the French pharmacopoeia [11] and the Japanese Pharmacopoeia [12]. The Austrian Pharmacopoeia requires not less than $5.00 \%$ glycoside derivatives, calculated as arbutin [13]. Additionally, the Swiss Pharmacopoeia requires not less than $8.00 \%[2,14]$, while the German pharmacopeia, not less than $6.00 \%$ of hydroquinone derivatives, calculated as anhydrous arbutin [15].

The content of arbutin can be determined in plant extracts by many methods including spectrophotometry and capillary zone electrophoresis, but the HPLC method was found to be the most suitable 
for arbutin separation, and it is recommended as the method of choice in the Ph.Eur.10.0. [10, 16].

There is a great demand for this herbal substance, and the natural populations of bearberry distributed on high carbonate slopes of many mountains in the Balkans represent a unique source of leaves. Bearberry thrives on rocky ground in the light woods of black and white pine and in subalpic plant communities on limestone and dolomite ground. Also the climate conditions and sea level are important conditions for this plant. Typically, bearberry can be found at over $1500 \mathrm{~m}$ above sea level on soils with high humidity, and it cannot be seen in urban areas. It is a common practice to collect the leaves during the flowering season of the plant (May till August). Usually, the wild harvesting of the leaves takes place during July, even though there is no evidence about its technical maturity. However, there is some data stating that the concentration of arbutin can be higher in autumn than in spring [16].

Commercially available plant materials derived from this species are still mainly coming from wild populations collected throughout Europe, primarily in the Balkans, Spain, Italy and the USSR [17]. The supply of this herbal material for R. N. Macedonia comes entirely from wild plants harvested in the mountains. There is an abundance of wild growing natural populations of bearberry on Korab Mountain, which spreads along the border of Albania and North Macedonia. This repre- sents a very important natural resource of this herbal substance for both countries.

Although A. uva-ursi L. is an indigenous species for this area, there is almost no literature data for the content of arbutin in the bearberry populations. Therefore, the aim of the present study was to determine the content of arbutin in seven different wild growing populations of $A$. uva-ursi from Korab Mountain and to assess the arbutin content variability relating to the altitude and the month of collection.

\section{EXPERIMENTAL SECTION}

\subsection{Plant material}

Leaves were collected from seven different natural populations ( $\mathrm{P} 1-\mathrm{P} 7)$ of A. uva-ursi from seven different mountain areas of Korab during the month of September 2015 (Table 1). Plant material from a single population (P5) was collected every month during the vegetation stage of the plant (from May to October) over a period of three years (2014-2016). Furthermore, this period included different stages of generative maturity (flower, fruit and after fruit). Plant identity was verified and voucher specimens were deposited at the Institute of Pharmacognosy, Faculty of Pharmacy, Skopje, N. Macedonia (Table 1). Leaves were air dried, packed in paper bags, and kept cold and in the dark until analysis.

Table 1

Collection data for the plant material from seven different natural populations $(P)$ of A. uva-ursi from Korab Mt., Albania

\begin{tabular}{|c|c|c|c|c|c|}
\hline \multirow{2}{*}{$\begin{array}{c}\text { Population } \\
\text { Voucher specimen* } \\
\end{array}$} & \multirow{2}{*}{ Locality } & \multirow{2}{*}{ Altitude (m) } & \multicolumn{2}{|c|}{ Geographic coordinates } & \multirow{2}{*}{ Orientation } \\
\hline & & & $\varphi$ & $\lambda$ & \\
\hline P1/Ko-Auv12 & Borovajk i Begjunecit & 1377 & $41^{\circ} 40^{\prime} 36,5^{\prime \prime}$ & $20^{\circ} 28^{\prime} 34,2^{\prime \prime}$ & north-east \\
\hline P2/ Ko-Auv06 & Gropat e Staneve & 1475 & $41^{\circ} 47^{\prime} 57,8^{\prime \prime}$ & $20^{\circ} 26^{\prime} 39,4^{\prime \prime}$ & north-east \\
\hline P3/ Ko-Auv11 & Mali i Vrenjtit & 1526 & $41^{\circ} 44^{\prime} 35,1^{\prime \prime}$ & $20^{\circ} 26^{\prime} 48,2^{\prime \prime}$ & north \\
\hline P4/ Ko-Auv08 & Llofkat e Sllatinës & 1615 & $41^{\circ} 47^{\prime} 26,3^{\prime \prime}$ & $20^{\circ} 27^{\prime} 44,1^{\prime \prime}$ & north-east \\
\hline P5/ Ko-Auv09 & Livadhi i Gjatë & 1655 & $41^{\circ} 47^{\prime} 8,7^{\prime \prime}$ & $20^{\circ} 28^{\prime} 7,3^{\prime \prime}$ & west \\
\hline P6/ Ko-Auv07 & Kodrat e Bregut & 1690 & $41^{\circ} 47^{\prime} 26,3^{\prime \prime}$ & $20^{\circ} 27^{\prime} 19,2^{\prime \prime}$ & south-west \\
\hline P7/ Ko-Auv10 & Perroi i Pasqyrës & 1868 & $41^{\circ} 46^{\prime} 56,9^{\prime \prime}$ & $20^{\circ} 28^{\prime} 43,9^{\prime \prime}$ & south-east \\
\hline
\end{tabular}

Extraction: $0.8 \mathrm{~g}$ of powdered dried leaves from bearberry were treated with $20 \mathrm{ml}$ of water $R$ under a reflux condenser on a water-bath for 30 min. The cold liquid was filtered through a plug of absorbent cotton which was further added to the residue in the $100 \mathrm{ml}$ flask and the extraction step was repeated one more time. The filtrates were combined and diluted to $50 \mathrm{ml}$ with water $R$. Afterwards, filtration through a paper filter was performed and the first $10 \mathrm{ml}$ were discarded. The water extracts were prepared according to the method described in the European Pharmacopeia $10.0,2020(2.2 .29)$ [10]. 
HPLC method: Chromatographic analyses were carried out using an HPLC system from the Agilent 1200 series by applying the method described in the Ph.Eur.10.0 monograph (01/2007: 1054) [10]. A Zorbax Eclipse XDB RP C-18 column $(150 \mathrm{~mm} \times 4.6 \mathrm{~mm}, 5 \mu \mathrm{m}$, Agilent, Germany) was used, and it was protected with a guard column $(4 \mathrm{~mm} \times 4.6 \mathrm{~mm}, \mathrm{RP}-18,5 \mu \mathrm{m}$, Agilent, Germany). The eluents were methanol $\mathrm{R}$ and water $\mathrm{R}, 10: 90(\mathrm{v} / \mathrm{v})$. The flow rate was $1.2 \mathrm{ml} / \mathrm{min}$, and the injection volume was $20 \mu \mathrm{l}$. The column temperature was maintained at room temperature, and detection was carried out at $280 \mathrm{~nm}$. Quantification of the samples for arbutin was performed immediately after extraction to avoid possible chemical alterations. A $1 \mathrm{mg} / \mathrm{ml}$ stock solution of arbutin standard was used as reference solution $a$ (arbutin, analytical standard, $\geq 98 \%$ HPLC, CAS 497-76-7, Fluka, Sigma-Aldrich) [10]. Reference solution $b$ (hydroquinone, USP, CAS 123-31-9 604-005-00-4, Sigma-Aldrich) was used for system suitability to obtain $\geq 4.0$ resolution (4.83) between the peaks due to arbutin and hydroquinone.

Arbutin content is expressed as a percent, and it was calculated according to the following equation in the Ph.Eur.10.0 monograph:

$$
\%=\left(F_{1} \times m_{2} \times p\right) /\left(F_{2} \times m_{1}\right)
$$

$F_{1}$ - area of the peak of arbutin from the chromatogram obtained with the analysis,

$F_{2}$ - area of the peak of arbutin from the chromatogram obtained with the reference solution $a$ $m_{1}$ - mass of the plant material used to prepare the analysis (in $\mathrm{g}$ ),

$m_{2}$ - mass of the arbutin standard used to prepare the reference solution $a$ (in $\mathrm{g}$ ),

$p$ - percentage content of arbutin in arbutin analytical standard.

\subsection{Data and statistical analysis}

Data are expressed as mean \pm standard deviation (SD) of triplicates $(n=3)$. One-way ANOVA was performed to evaluate the connection between the altitude $(\mathrm{m})$ of the collection site and the arbutin content of seven different wild populations of A. uva-ursi. Tukey's post hoc analysis was employed. The paired t-test was used to compare the content of arbutin (\%) within three years (20142016). All statistical analyses were conducted with the IBM SPSS Statistics Subscription Trial (Classic), 2020 software at a significance level of 0.05 .

\section{RESULTS AND DISCUSSION}

The content of arbutin, (expressed as \% of anhydrous arbutin) was determined with the HPLC method. The highest content of arbutin was found in population P1 $(9.42 \%)$ and the lowest in population P6 (7.03 \%) samples collected in autumn 2015 (Figure 1). These results cohere with the data published by Parejo et al. [16] which showed that the arbutin content of bearberry leaves in autumn from four locations in Spain was found to vary from 6.30 to $9.16 \%$, expressed on a dry weight basis.

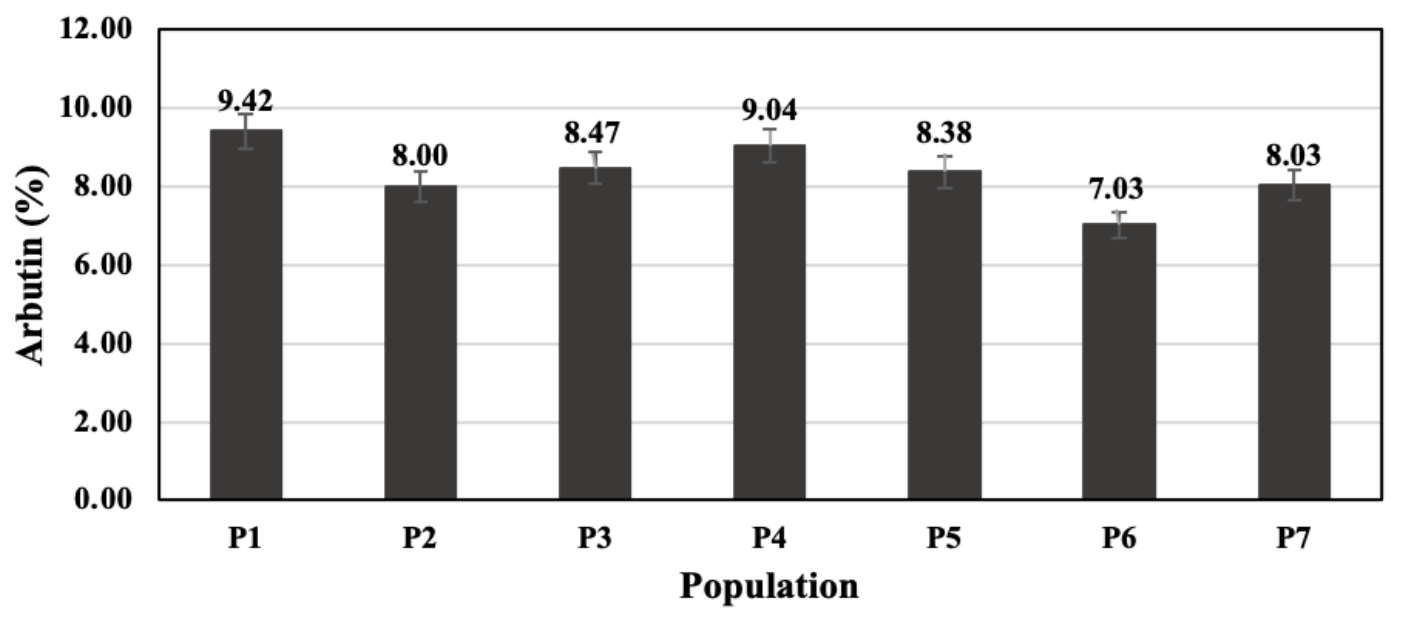

Fig. 1. The content of arbutin (\%) in seven different natural populations (P) of A. uva-ursi from Korab Mt., autumn $2015(n=3)$ 
The analysis of the plant material from a single population (P5), collected every month during the vegetation stage of the plant (from May to October) in a period of 3 years from 2014 to 2016, showed that the highest content of arbutin was determined in September/October (Figure 2).

There was a statistically significant difference between the populations' arbutin content as determined by one-way ANOVA $(p=0.000)$. Regarding the altitude of the collection site, a Tukey post hoc test revealed that there is a statistically significant difference which was observed between the 2 populations ( $\mathrm{P} 1$ and $\mathrm{P} 7$ ) collected from the lowest $(1377 \mathrm{~m})$ and the highest $(1868 \mathrm{~m})$ point from Korab Mountain $(p=0.011)$. On the other hand, there was no statistically significant difference in the arbutin content of bearberry populations harvested at altitudes bellow $1660 \mathrm{~m}(\mathrm{P} 1=$ $1377 \mathrm{~m}, p=0.073 ; \mathrm{P} 2=1475 \mathrm{~m}, p=0.894 ; \mathrm{P} 3=$ $1526 \mathrm{~m}, p=1.000$, and $\mathrm{P} 4=1615 \mathrm{~m}, p=0.440$ ). The plant material harvested from $1690 \mathrm{~m}$ altitude (P6) showed a statistically significant difference in arbutin content compared with the populations (P1, P3, P4 and P5) of A. uva-ursi collected from 1377 $\mathrm{m}, 1526 \mathrm{~m}, 1615 \mathrm{~m}$ and $1655 \mathrm{~m}$ a.s.l. $(p=0.000$,
$0.008,0.000$, and 0.013 , respectively), and it showed no difference from population P2 $(1475 \mathrm{~m}$ a.s.l., $p=0.105)$ and $\mathrm{P} 7$ (1868 $\mathrm{m}$ a.s.l., $p=0.927)$. By analyzing the data from the 3 years, we can also assume that the arbutin content extracted from the plant material collected in 2014 and 2016 showed no statistical differences between these two years (2014-2016, $p=0.337)$. However, the content of arbutin was noticeably higher during all months of 2015 and showed statistical differences compared with the other two years (2014-2015, $p$ $=0.004 ; 2015-2016, p=0.002)$. Even so, a coherent monthly tendency and repeatability can be observed throughout the three years. Furthermore, the results from the analysis of the leaves collected at different stages of generative maturity showed that the highest content of arbutin can be noticed in the phase after the fruit $(7.29 \%)$ rather than in the phases of flowering (6.42\%) or fructification (6.59 $\%)$. Parejo et al. [16] also published results stating that autumn is a better period than spring for the collection of plant material in order to obtain a higher yield of arbutin. Some reports show that the arbutin content is the highest in December and January and also when the leaves are dried rapidly [1].

Technical maturity of A. uva-ursi

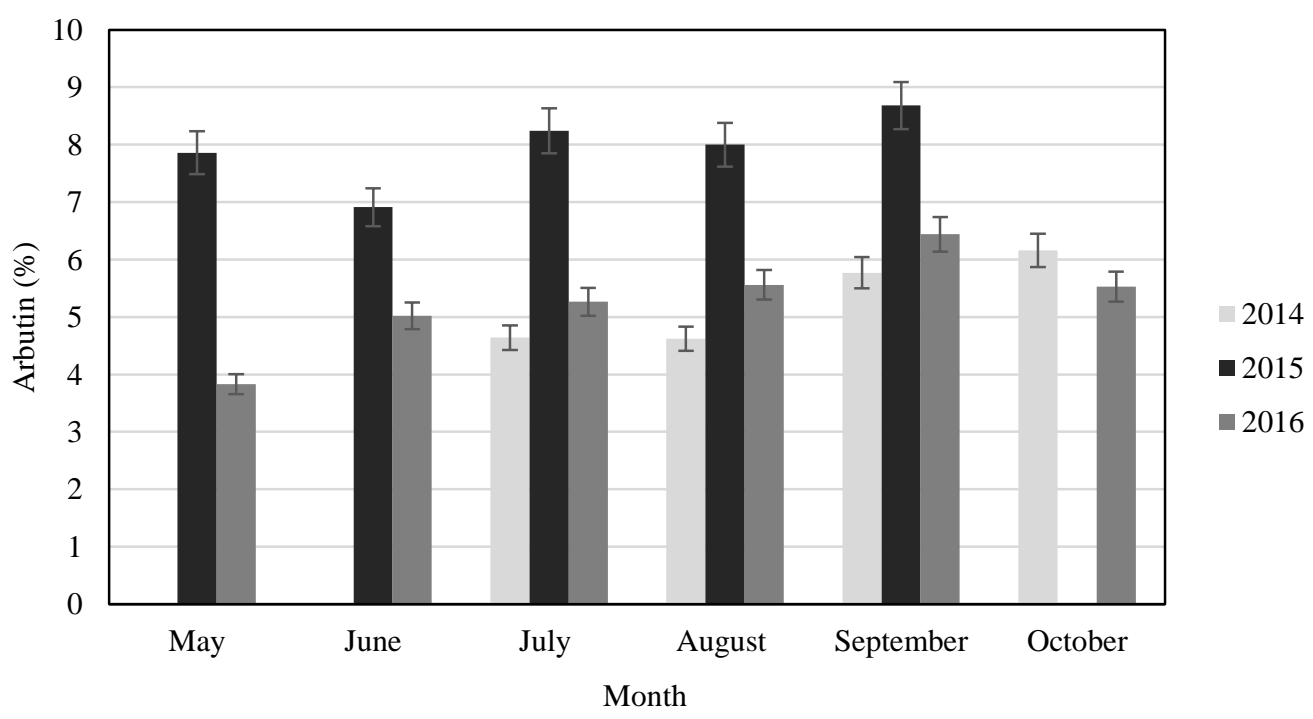

Fig. 2. Monthly content of arbutin (\%) (May-October 2014, 2015 and 2016) of P5 of A. uva-ursi from Korab Mt.

\section{CONCLUSION}

All seven examined wild growing natural populations of bearberry from Mt. Korab possessed arbutin content over $7.00 \%$ (7.03-9.42 \%) and comply with the Ph.Eur.10.0. standards. The highest content of arbutin was obtained in the ma- terial collected in September/October, after the fructification. A difference between the content of the arbutin in different populations, regarding the altitude of the collection site and the collection period, was observed. Bearberry natural populations on Mt. Korab, which spreads along the border of Albania and North Macedonia, represent a very 
important natural resource of bearberry herbal material for both countries.

Author contribution statement: G. S. and I. C. K. performed chemical and data analyses and wrote the manuscript. V. L. and O. K. participated in the experimental work. Z. G. and N. B. provided the plant material. M. K., B. Q. and S. K. scientifically improved and corrected the manuscript.

\section{REFERENCES}

[1] Committee on Herbal Medicinal Products (HMPC), Final assessment report on Arctostaphylos uva-ursi (L.) folium. EMA/HMPC/750266/2016. Accessed April $11 / 2018$.

https://www.ema.europa.eu/en/documents/herbalreport/final-assessment-report-arctostaphylos-uva-ursi-1spreng-folium-revision-2_en.pdf

[2] M. Wichtl (Ed.), Herbal Drugs and Phytopharmaceuticals. A Handbook for Practice on a Scientific Basis. Stuttgart, Medpharm Scientific Publishers, 1994.

[3] Missouri Botanical Garden, Arctostaphylos uva-ursi, 4344 Shaw Blvd., St. Louis, MO 63110, 2020. https://www.missouribotanicalgarden.org/PlantFinder/Pl antFinderDetails.aspx ?taxonid $=279933 \&$ isprofile $=0 \&$

[4] D. Frohne, Arctostaphylos uva-ursi (L.) Spreng. (Bärentraube). Kooperation Phytopharmaka. Unpublished review, Bonn (1997).

[5] WHO, Folium Uva ursi Monograph (2004) 2, 342-351. Accessed December 21, 2011. http://apps.who.int/medicine-docs/pdf/s4927e/s4927e.pdf.3

[6] K. Kraft, C. Hobbs, Pocket Guide to Herbal Medicine, 3. Medical Plants from A to Z, Thieme, New York, United States, 2011. DOI: 10.1055/b-0034-55385

[7] ESCOP. 1997. 'Uvae ursi folium.' Monographs on the Medicinal Uses of Plant Drugs. Exeter, U.K.: European Scientific Cooperative on Phytotherapy.

[8] K. Jurica, I. Brčić Karačonji, S. Šegan, D. Milojković Opsenica, D. Kremer, Quantitative analysis of arbutin and hydroquinone in strawberry tree (Arbutus unedo L., Ericaceae) leaves by gas chromatography-mass spectrometry. Arh. Hig. Rada Toksikol. 66, 197-202 (2015). DOI: 10.1515/aiht-2015-66-2696

[9] L. Jahodář, P. Jílek, M. Páktová, V. Dvořáková, Antimicrobial effect of arbutin and an extract of the leaves of Arctostaphylos uva-ursi in vitro. Česk. Farm. 34, 174178 (1985).

[10] European Pharmacopoeia, 10th Ed. Council of Europe, Strasbourg, France, 2020. Bearberry Leaf - Uvae ursi folium, 01/2007:1054.

[11] Pharmacopée Française, X edition (Ph.Fr.X.). 19831990. Moulins-les-Metz: Maisonneuve S.

[12] Japanese Pharmacopoeia, 12th ed. (JP XII). Tokyo: Government of Japan, Ministry of Health and Welfare, Yakuji Nippo, Ltd. 4446, 1993.

[13] Sterreichisches Arzneibuch, Vols. 12, $1^{\text {st }}$ suppl. (AB). 1981-1983. Wien: Verlag der sterreichischen Staatsdruckerei, 1981.

[14] Pharmacopoeia Helvetica, 7th ed. Vol. 14. (Ph.Helv.VII), Bern: Office Central Fdral des Imprims et du Matriel, 1987.

[15] Deutsches Arzneibuch, 10th ed., 3rd suppl. (DAB 10), Stuttgart: Deutscher Apotheker Verlag, 1994.

[16] I. Parejo, F. Viladomat, J. Bastida, C. Codina, A single extraction step in the quantitative analysis of arbutin in bearberry (Arctostaphylos uva-ursi) leaves by highperformance liquid chromatography. Phytochem. Anal. 12, 33-339 (2001). DOI: 10.1002/pca.602

[17] National Toxicology Program, National Institute of Environmental Health Sciences, National Institutes of Health, U.S Department of Health and Human Services, Research Triangle Park, NC, Chemical Information Review. Document for Arbutin [CAS No. 497-76-7] and Extracts from Arctostaphylos uva-ursi - Supporting Nomination for Toxicological Evaluation by the National Toxicology Program, January 2006.

https://ntp.niehs.nih.gov/ntp/htdocs/chem_background/e xsumpdf/arbutin_508.pdf 